\title{
nature
}

\section{Higher education in trouble}

\section{The debate about the British government's plans for its universities will soon begin in earnest, but the objectives of the intended changes are far from clear.}

WITH the British parliament back from its holidays this week, the government's plans for education are back on the agenda. Or some of them are. The House of Commons has already begun going through the huge education bill clause by clause. Soon it will have sunk its teeth into the most contentious parts of Mr Kenneth Baker's bill - those giving schools the right to opt out of local authority control and parents the right to choose where they send their children. What with a budget looming up, there will not be much serious discussion of the bill's proposals on higher education until it gets to the House of Lords early in the summer. Only if it is then amended in ways the government considers unacceptable is it certain that the half of the British parliament enjoying electoral legitimacy will explicitly consider the most radical changes this century in British higher education.

That, by itself, is a striking measure of how times have changed in Britain. The universities in particular have been politically friendless for a long time now - at least for a decade, perhaps since the formal designation of the polytechnic system ten years earlier. Those who doubt that should dig out the prospectuses offered by the opposition parties at last year's general election. None promised the restoration of financial or moral independence to the universities, but each offered a different recipe for bending higher education to different national objectives. The opinion that, out of self-preoccupation and indifference, British universities have failed the national economy is widely held. The fact that the complaint is untrue is almost neither here nor there, for it is the motivation of the parts of the Education Reform Bill touching higher education.

A curious situation has arisen that will, it is hoped, be explored at the seminar Nature is holding next week in London (see box). Mr Kenneth Baker, Mrs Thatcher's third Secretary of State for Education and Science (before Sir Keith Joseph was a Mr Mark Carlisle, remember?) is potentially the most interesting yet, but has been in the job for only a year. Not surprisingly, his education bill brings together several strands of government opinion - suspicion of elected local authorities (opting out and the abandonment of the pretence that polytechnics are run by local authorities), populism (parental choice), the maintenance of standards (periodic achievement tests in elementary and secondary schools), public accountability for the spending of public money (the tight accounting rules by which universities will live under the bill, if enacted) and the belief that business, the engine of economic growth, knows best (whence the stipulation that the Universities Funding Council will have a businessman, not yet selected, as its chairman). Yet despite the explicitness of the new recipe for higher education on procedural matters, neither the bill nor the white paper which preceded it

\section{The education bill: reform or otherwise?}

A seminar on the implications of the Education Reform Bill organized by Nature will be held in London on the afternoon of 19 January. The principal speaker will be Sir Mark Richmond, Vice-Chancellor of the University of Manchester and Chairman of the Committee of Vice-Chancellors and Principals. Those wishing to attend should apply for tickets and further information to Mary Sheehan (01-836 6633 extension 2223). last summer adequately describes the objectives of the purported reforms. Even the British government's critics are forced to guess at what may be in its mind.

The most charitable opinion is that the British government honestly believes it can further help to make Britain a more prosperous place (its achievements in that regard by other means should not be sniffed at) by making higher education walk a more clearly defined line. But with what objective? The British government does not acknowledge the peculiar character of higher education, which is the process of educating adults destined demographically to outlast their teachers and, on the side, of sustaining scholarship (by research). The government agrees with Britain's academics that the two activities are essential (but not necessarily that they are also, at some level, inseparable). The weakness of its philosophy of reform is that it seems to regard each of these functions as a commodity whose supply must be increased. Britain needs more educated people, so they must be trained, while research has economic value; if it happens that it cannot be exploited domestically, at least the patent rights may be saleable.

But higher education is not just another kind of business. The supply of its products, in the British government's idiom, may be only crudely related to the demand (or need). Thus Britain is in desperate need of more and more skilled technical people, but will the young devote themselves to a profession sullied in public reputation by the shrunken payrolls of the past few years? And while researchers working in partnership with industry may stand a chance of making a fortune now and again, what is to happen to those with an intellectual interest in other things? The other implicit misconception underlying the bill is that the universities, dependent as they are on public funds, should be compliant with the undefined inclinations of their sponsors, is equally mistaken. It is a plain truth that the most socially valuable of universities are often the most heterodox. (Where would the Thatcher government be if it had not been for the monetarist heterodoxy of the University of Chicago in the 1960s?) Higher education will not be worth having if it ceases to be subversive of present ideals, which is the real reason why its institutions need to be structurally autonomous. The British government will not help itself by the centralism around which its reforms are built.

On the bill, academics might take this line. The pinpricks, such as the proposal to extinguish academic tenure, are not as important threats to academics' freedom as they have been made out to be; academics could be fired only when the need for their services had disappeared, and universities (not the government) would be the judges of when that circumstance had materialized. The central issues are the provisions that the funding council may attach conditions to the grants it makes to particular universities and that the government may direct the funding council to attach conditions. Those who know the way the present system works are in two camps: some say that even present customs give the central government absolute power which it dares not exercize for fear of the fuss that there would be. Others, however, note that the mere existence of a constitutional right of interference from the centre gives civil servants a sense of mission to interfere. The serious threat is that British 